\title{
Solids Loading Limitations of Rectangular Secondary Clarifiers
}

\author{
Orris E. Albertson, P.E. ${ }^{1}$
}

\begin{abstract}
Basin configuration and equipment design govern whether rectangular secondary clarifiers will experience problems of inadequate sludge transport capacity. The operating factors to be considered, other than peak flows which may be severe, are the potential for sludge bulking and the higher mixed liquor suspended solids concentrations and solids retention times employed for biological nutrient removal processes. Rectangular clarifiers longer than $20 \mathrm{~m}$ and loaded at more than $3.5 \mathrm{~kg} / \mathrm{m}^{2}$ day often have sludge transport/ shortcircuiting problems. Shortcircuiting of mixed liquor into the return sludge is a common situation that can be avoided in new designs and easily corrected in existing facilities. A step-by-step design approach is presented as a series of process calculations with graphs. Results from the unmodified and the improved rectangular clarifiers at Phoenix 91st Avenue wastewater treatment plant, Ariz., are presented.
\end{abstract}

DOI: 10.1061/(ASCE)0733-9372(2008)134:1(14)

CE Database subject headings: Activated sludge; Transport rate; Loading rate; Solid wastes; Wastewater treatment.

\section{Background}

Rectangular clarifiers that have previously worked well in secondary treatment at mixed liquor suspended solids (MLSS) of $1,000-2,000 \mathrm{mg} / \mathrm{L}$ may suffer a significant reduction in capacity when employed for MLSS of 3,000-4,000 $\mathrm{mg} / \mathrm{L}$ in biological nutrient removal (BNR) processes. This situation can occur even with sludge volume indices (SVIs) less than $150 \mathrm{~mL} / \mathrm{g}$. Sludge bulking conditions, which result in excessive sludge accumulation in rectangular clarifiers, may also be a factor of reduced capacity. In these cases, the solids loading rate (SLR), $\mathrm{kg} / \mathrm{m}^{2}$ day, will be the limiting factor. The transport capacity of the scraper mechanism will often limit the capacity of rectangular basins to process efficiently higher MLSS concentrations and/or peaking flows. There are other known influences on the performance and capacity of the clarifiers: namely, entrance conditions, counter- or cocurrent influent/sludge flow, depth of the basin, slope of the floor, and the design of the influent structure. However, these conditions have been widely discussed in the literature (Albertson 1992, 2005; IAWQ 1997; ASCE 1998) and are mostly independent of this analysis, with the exception of floor slope, direction of flow, and collected solids, which are discussed in this paper.

Very little public information is available on the transport capacity of rectangular clarifier mechanisms in secondary treatment. No guidance is found in the comprehensive ASCE (1998) design manual. Kalbskopf (1972) reported that the underflow or return suspended solids (RSS) of Emschergenossenschaft and Lippeverband secondary clarifiers were equal to the result of a constant/ SVI or

\footnotetext{
${ }^{1}$ President, Enviro Enterprises, Inc., P.O. Box, 117, LaBarge, WY 83123. E-mail: envirotj@aol.com

Note. Discussion open until June 1, 2008. Separate discussions must be submitted for individual papers. To extend the closing date by one month, a written request must be filed with the ASCE Managing Editor. The manuscript for this paper was submitted for review and possible publication on October 19, 2006; approved on July 19, 2007. This paper is part of the Journal of Environmental Engineering, Vol. 134, No. 1, January 1, 2008. CASCE, ISSN 0733-9372/2008/1-14-23/\$25.00.
}

$$
\operatorname{RSS}(\mathrm{mg} / \mathrm{L})=12,000(100 / \mathrm{SVI})
$$

This relationship was valid over the range of $100-200 \mathrm{~mL} / \mathrm{g}$, but the writer noted that the RSS was underpredicted at SVIs less than $100 \mathrm{~mL} / \mathrm{g}$. In an earlier paper, Kalbskopf (1970) suggested the SLRs for a rectangular clarifier should be limited as a function of the SVI. The values suggested were as follows:

\begin{tabular}{lcc}
$\begin{array}{l}\mathrm{SVI} \\
(\mathrm{mL} / \mathrm{g})\end{array}$ & $\begin{array}{c}\text { SLR } \\
\left(\mathrm{lb} / \mathrm{ft}^{2} \text { day }\right)\end{array}$ & $\begin{array}{c}\mathrm{SLR} \\
\left(\mathrm{kg} / \mathrm{m}^{2} \mathrm{~h}\right)\end{array}$ \\
\hline 100 & $<17.2$ & $<3.5$ \\
200 & $5.4-6.4$ & $1.1-1.3$ \\
300 & $4.3-5.4$ & $0.8-1.1$
\end{tabular}

While it was recognized that the sludge volume to be removed increased as a function of the SVI and the SLR, there was neither discussion of possible limitations imposed by the sludge collection equipment nor of any opportunities to increase SLRs.

The problem of mixed liquor shortcircuiting to the underflow and dilution of the return sludge is common to both circular and rectangular basins. The Federal Water Quality Administration (FWQA), now USEPA, conducted dye studies in a number of facilities in the 1960s that revealed the magnitude of shortcircuiting.

Pfeffer et al. (1968) reported on dye studies conducted on the 4-31.1 m long $\times 10.1 \mathrm{~m}$ wide $\times 2.90 \mathrm{~m}$ sidewater depth (SWD) rectangular clarifiers at the Pontiac, Mich. wastewater treatment plant (WWTP). The dye appeared in the return sludge (Fig. 1), within $5 \mathrm{~min}$ and peaked at less than $10 \mathrm{~min}$ after dye was added prior to the inlet. Myers et al. (1968) conducted dye studies on the $30.5 \mathrm{~m}$ diameter $\times 2.44 \mathrm{~m}$ SWD circular clarifiers and also found that the dye peaked in the underflow within $5 \mathrm{~min}$ after addition to the feedwell. They concluded that $50 \%$ of the return sludge flow was mixed liquor shortcircuiting to the sludge hopper. These studies, other FWQA studies, and European reports indicate that shortcircuiting was endemic to secondary clarifiers and the effective corrective action for circular clarifiers was to increase 


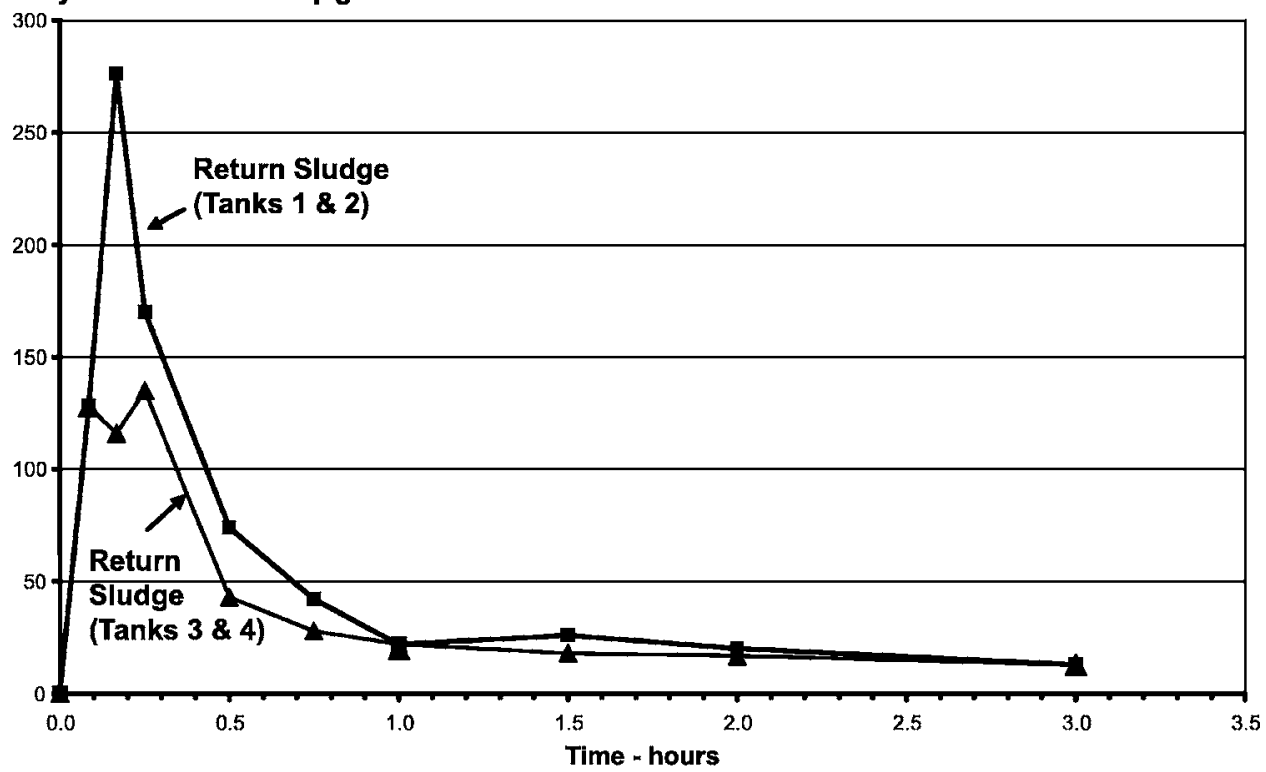

Fig. 1. Pontiac, Mich. rectangular clarifier dye study (adapted from Pfeffer et al. 1968)

the sludge transport capacity by $400-800 \%$, depending on the clarifier size.

Günthert (1984) evaluated the solids handling capacity of several circular clarifiers and the result of his analysis was a deepening of the spiral blades to increase the transport capacity and limit shortcircuiting. It is now standard practice (Albertson and Okey 1992) to determine the mechanical transport requirements and tailor the size and speed of spiral blades to meet the design requirements of circular clarifiers. In the past 15 years, the tapered and deep spiral scrapers have proven their performance in thousands of clarifiers worldwide and can be considered standard practice now in the United States and abroad. Thus, this same type of analysis was conducted to establish the methodology to determine the transport requirements for longitudinal and cross collectors of rectangular clarifiers.

\section{Discussion of Methodology}

The approach to an evaluation of the solids capacity of an existing basin versus a new design will be similar. In each case, the limitation will be the capacity of the longitudinal scrapers to transport the sludge along the basin floor to the trough and then to remove collected sludge from the transverse trough. The critical point in a counterflow (liquid and sludge) basin will be near the trough where the settled sludge has reached its maximum volume and depth. The sludge deposited into the trough must then be conveyed to the hopper for removal.

Extensive testing of cocurrent and counterflow zones in secondary clarifiers (Albertson and Coughenour 1995) was conducted on the $8-12.2 \mathrm{~m}$ wide $\times 57.9 \mathrm{~m}$ long by $3.99 \mathrm{~m}$ SWD secondary clarifiers at Phoenix, Ariz. These tests, using a "sludge judge," revealed that the scrapers could not transport more sludge than their theoretical displacement even when the sludge depth exceeded the scraper height. In fact, prior to modifying the inlet to reduce influent energy and installing the waterfall wall baffle, the mixed liquor flow in the cocurrent zone washed out settled sludge within the scraper depth. A movie tape (courtesy of Envirex 1953) of a countercurrent sludge scraper viewed through a glass wall revealed that the counterflow condition reduced the capacity of the scraper arrangement but not in the cocurrent mode. However, the Envirex movie revealed that the transported sludge depth was equal to or less than the scraper height in the countercurrent mode, which was confirmed in the 91st Avenue test. Thus, control of influent flow energy and waterfall effects by distribution/dispersion/redirection is also important to the successful operation of the collection system.

The Envirex movie and extensive tests of Phoenix 91st Avenue strongly corroborate the premise that hydraulic forces in the sludge blanket are counteracted by overriding liquid flow and mechanical motivation is necessary and must be consistent with the quantity of sludge volume to be transported.

The theoretical mechanical displacement or capacity [Eq. (1)] of a scraper blade is determined in the following manner:

1. Theoretical scraper capacity $-V_{\mathrm{SC}}\left(\mathrm{m}^{3} / \mathrm{min}\right)$

$$
\text { Theoretical } V_{\mathrm{SC}}=\left(L_{\mathrm{SC}}, \mathrm{m}\right)\left(h_{\mathrm{sf}}, \mathrm{m}\right)\left(v_{s}, \mathrm{~m} / \mathrm{min}\right)
$$

where $L_{\mathrm{SC}}=$ length of scraper-tank width $(\mathrm{m}) ; h_{\mathrm{sf}}=$ height of the scraper flight $(\mathrm{m})$; and $v_{s}=$ velocity of the scraper ( $\mathrm{m} / \mathrm{min})$.

2. Return activated sludge (RAS, $\mathrm{m}^{3} / \mathrm{h}$

$$
\mathrm{RAS}=[(\mathrm{MLSS}, \mathrm{mg} / \mathrm{L}) /(\mathrm{RSS}-\mathrm{MLSS}, \mathrm{mg} / \mathrm{L})] Q, \mathrm{~m}^{3} / \mathrm{h}
$$

where $Q=$ wastewater flow $\left(\mathrm{m}^{3} / \mathrm{h}\right) ; \mathrm{MLSS}=$ mixed liquor suspended solids $(\mathrm{mg} / \mathrm{L})$; and $\mathrm{RSS}=$ return sludge suspended solids $(\mathrm{mg} / \mathrm{L})$.

3. Solids loading rate $=$ SLR ( $\mathrm{kg}$ total suspended solids (TSS) $/ \mathrm{m}^{3}$ day)

$$
\mathrm{SLR}=\left(Q+\mathrm{RAS}, \mathrm{m}^{3} / \mathrm{h}\right)\left(\mathrm{MLSS}, \mathrm{kg} / \mathrm{m}^{3}\right)(8.34) / A_{\mathrm{CL}}
$$

where $A_{\mathrm{CL}}=$ clarifier area, length $\times$ width $\left(\mathrm{m}^{2}\right)$.

The actual, not theoretical, scraper capacity $\left(V_{\mathrm{SC}}\right)$ must exceed the 


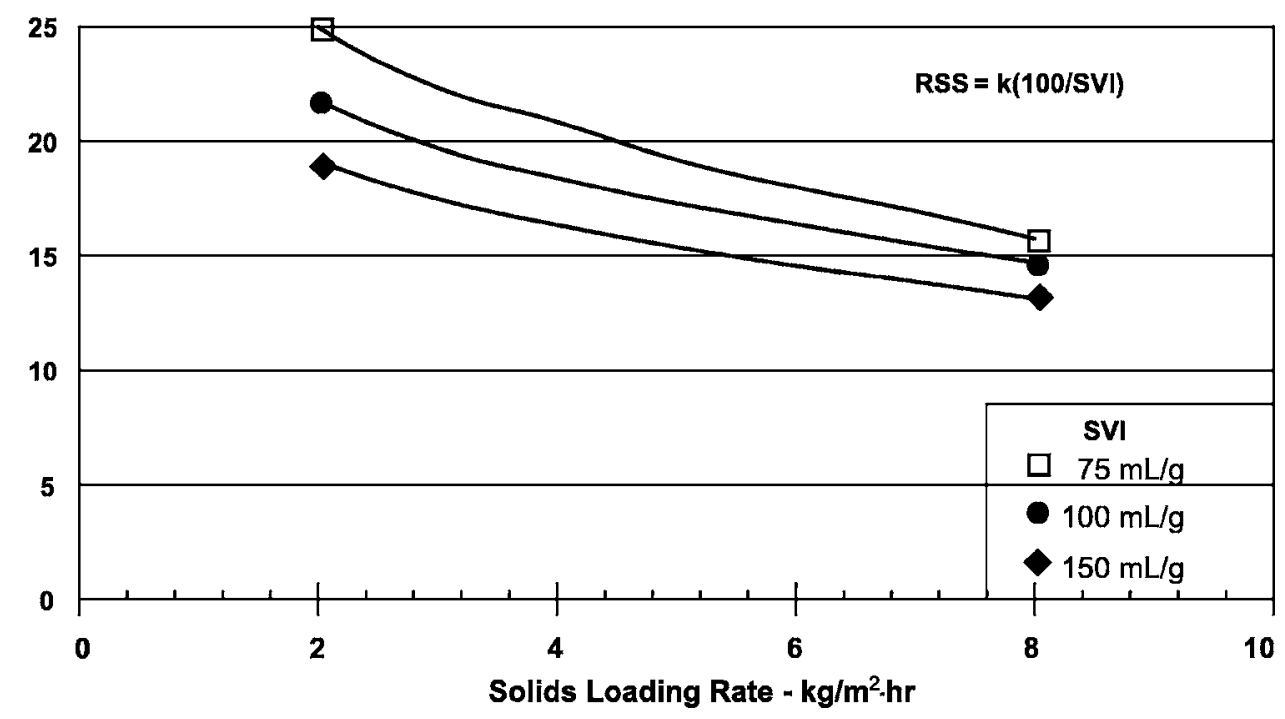

Fig. 2. Rearranged Daigger (1995) graphs to define $k$ value (adapted from Daigger 1995)

underflow rate (RAS) or there will be shortcircuiting by the overlying mixed liquor. Shortcircuiting would dilute the underflow, a higher recycle rate would be required, and the SLR would be increased. The shortcircuiting will be eliminated when the solids concentration within the flights near the sludge trough is the same as the RSS concentration. Samples can be taken with a sludge judge to determine sludge concentrations near the floor and within the height of the flight next to the hopper.

The ideal condition will be when the settled sludge reaches the concentration consistent with the SLR and the SVI (or dilute SVI, DSVI) of the MLSS. Such a relationship has been described by Daigger and Roper (1985) and Daigger (1995) and other researchers. The Daigger data (Daigger 1995) have been rearranged into the equation form presented by Kalbskopf (1972) or

$$
\mathrm{RSS}=k(100 / \mathrm{SVI})
$$

where $k=$ concentration factor as a function of the SLR and the SVI of the MLSS.

The Daigger (1995) relationship was developed from the initial Daigger-Roper studies and supplemented by full-scale test results from several sources and represented over 1,500 data points. The modification of the Daigger SVI diagram to the Eq. (4) format is presented in Fig. 2. Kalbskopf employed this equation using a constant $k$ value of $12,000 \mathrm{mg} / \mathrm{L}$, but the $k$ value is influenced by the SLR as indicated by the Daigger curves. The Kalbskopf data also showed an increasing $k$ value when the SVI was less than $100 \mathrm{~mL} / \mathrm{g}$, but this was not reflected in his equation. Similar relationships for dilute SVI (DSVI) and stirred SVI at $3.5 \mathrm{~g} / \mathrm{L}$ MLSS $\left(\mathrm{SVI}_{3.5}\right)$ can be developed using the Daigger data.

There is the unanswered question of the actual fraction of the sludge blanket which is at underflow concentration. The scraper mechanism continuously mixes the settled sludge and some data indicate that the average concentration of the discrete (dense) blanket may be equal to or greater than 0.8 of sludge TSS concentration within the flights. However, there will be a dilute sludge blanket of partially consolidated MLSS flowing across the top of the denser blanket toward the effluent launder. A second question revolves around the normal or required average sludge blanket retention time (SBRT) in a clarifier sludge blanket. Field data vary widely for many reasons, but an average sludge blanket retention time of 45-60 min is suggested by this writer.

The underflow concentrations predicted by the curves and the equation in Fig. 2 are significantly higher (50-150\%) than typically achieved in United States rectangular secondary clarifiers. Since there is a data variation, some allowance must be made to ensure that the end result is a reliable design. While most of the Daigger $k$ values are higher than the Kalbskopf value, this suggests that the higher RSS concentrations are achievable if the equipment is properly configured.

Selection of the factor for reducing the value of $k$ for the design $k$ would be site specific and based on the maximum month SLR and highest maximum weekly SVI conditions. Until there is more field research and data in this area, a value of $0.70 k$ for the design RSS underflow and 0.80 of the design RSS for the average sludge blanket suspended solids (SBSS) concentration is suggested as a prudent approach. Process calculations to determine the solids loading limitations in rectangular secondary clarifiers employed the operational parameters set forth below:

Example

$$
\begin{aligned}
& \mathrm{SLR}=4.1 \mathrm{~kg} / \mathrm{m}^{2} \mathrm{~h} \text { (maximum month) } \\
& \mathrm{SVI} \leqslant 125 \mathrm{~mL} / \mathrm{g} \text { (maximum week) }
\end{aligned}
$$

$$
\text { Daigger RSS = 19,600 mg/L (Fig. 2) }
$$

$$
\begin{aligned}
\text { Design RSS } & =(0.70)(19,600 \mathrm{mg} / \mathrm{L})[(100 \mathrm{~mL} / \mathrm{g} / 125 \mathrm{~mL} / \mathrm{g})] \\
& =11,000 \mathrm{mg} / \mathrm{L}\left(11.0 \mathrm{~kg} / \mathrm{m}^{3}\right)
\end{aligned}
$$

Average SBSS $=(0.8)(11,000 \mathrm{mg} / \mathrm{L})=8,800 \mathrm{mg} / \mathrm{L}\left(8.8 \mathrm{~kg} / \mathrm{m}^{3}\right)$

The selection of the highest weekly SVI value is critical to the design. Operation at SVIs greater than design increases the sludge blanket volume and quantity of sludge to be transported due to the lower solids concentrations. When there are SVI excursions, operators typically reduce the MLSS, lowering the SLR of the clarifiers. This may not be a viable option for biological nutrient removal (BNR) plants without sacrificing performance and/or treatment capacity. The above design values provide the informa- 
Table 1. Scraper Transport Requirements versus Basin Length at $4.07 \mathrm{~kg} / \mathrm{m}^{2}$ days SLR

\begin{tabular}{|c|c|c|c|c|c|}
\hline Basin length to hopper (m) & 12.2 & 24.4 & 36.6 & 48.8 & 61.0 \\
\hline Sludge quantity (RAS) $\left(\mathrm{m}^{3} / \mathrm{min} \mathrm{m}\right)$ & 0.0750 & 0.150 & 0.225 & 0.300 & 0.375 \\
\hline Minimum capacity $\left(V_{\mathrm{SC}}\right)\left(\mathrm{m}^{3} / \min \mathrm{m}\right)^{\mathrm{a}}$ & 0.0939 & 0.188 & 0.281 & 0.375 & 0.467 \\
\hline Theoretical flight capacity $\left(\mathrm{m}^{3} / \mathrm{min} \mathrm{m}\right)$ & - & - & - & - & - \\
\hline $190 \mathrm{~mm}$ at $0.61 \mathrm{~m} / \mathrm{min}$ & 0.116 & $0.116^{\mathrm{b}}$ & - & - & - \\
\hline $190 \mathrm{~mm}$ at $0.91 \mathrm{~m} / \mathrm{min}$ & - & $0.174^{\mathrm{b}}$ & - & - & - \\
\hline $190 \mathrm{~mm}$ at $1.22 \mathrm{~m} / \mathrm{min}$ & - & 0.232 & $0.232^{\mathrm{b}}$ & - & - \\
\hline $190 \mathrm{~mm}$ at $1.52 \mathrm{~m} / \mathrm{min}$ & - & - & 0.290 & - & - \\
\hline $381 \mathrm{~mm}$ at $0.61 \mathrm{~m} / \mathrm{min}$ & - & - & $0.232^{\mathrm{b}}$ & $0.232^{\mathrm{b}}$ & - \\
\hline $381 \mathrm{~mm}$ at $0.91 \mathrm{~m} / \mathrm{min}$ & - & - & 0.348 & $0.348^{\mathrm{b}}$ & - \\
\hline $381 \mathrm{~mm}$ at $1.22 \mathrm{~m} / \mathrm{min}$ & - & - & - & 0.464 & $0.464^{\mathrm{b}}$ \\
\hline $381 \mathrm{~mm}$ at $1.52 \mathrm{~m} / \mathrm{min}$ & - & - & - & - & 0.580 \\
\hline
\end{tabular}

${ }^{\mathrm{a}}$ Theoretical minimum design transport capacity $=1.25$ return flow (RAS).

${ }^{\mathrm{b}}$ Inadequate transport capacity or $<$ minimum capacity required.

tion required to define the sludge volume to be transported, sludge depth $\left(d_{s}\right)$, and the sludge blanket volume (SBV).

Next, define sludge blanket unit volume at $50 \mathrm{~min}$ retention time $\left(\mathrm{SBV}_{50}\right)$

$$
\begin{aligned}
\mathrm{SBV}_{50}= & (\mathrm{SLR})\left(10^{6}\right)(\mathrm{SBRT}) /(\mathrm{SBSS})(60)=\left(4.07 \mathrm{~kg} / \mathrm{m}^{2} \text { day }\right)\left(10^{6}\right) \\
& \times(50 \mathrm{~min}) /\left(8.8 \mathrm{~kg} / \mathrm{m}^{3}\right)(60 \mathrm{~min} / \mathrm{h}) \\
= & 0.385 \mathrm{~m}^{3} / \mathrm{m}^{2} \text { in the basin or } 0.385 \mathrm{~m} \text { average } \\
& \text { sludge depth }
\end{aligned}
$$

\section{Longitudinal Collectors}

Determine the sludge transport capacity $\left(V_{\mathrm{SC}}\right)$ and average sludge depth $\left(d_{s}\right)$ to be continuously removed by the collectors to maintain 50 min sludge retention time $\left(\mathrm{SBV}_{50}\right)$

$$
\begin{aligned}
V_{\mathrm{SC}}= & \left(\mathrm{SBV}_{50}\right)(\mathrm{SBSS} / \mathrm{RSS})(60 / \mathrm{SBRT})=\left(0.385 \mathrm{~m}^{3} / \mathrm{m}^{2}\right) \\
& \times\left[\left(8.8 \mathrm{~kg} / \mathrm{m}^{3}\right) /\left(11.0 \mathrm{~kg} / \mathrm{m}^{3}\right)\right](60 \mathrm{~min} / \mathrm{h} / 50 \mathrm{~min} / \mathrm{h}) \\
= & 0.37 \mathrm{~m}^{3} / \mathrm{m}^{2} \mathrm{~h} \text { or } 370 \mathrm{~mm} / \mathrm{h}
\end{aligned}
$$

The scrapers must be designed to remove $370 \mathrm{~mm} / \mathrm{h}\left(d_{s}\right)$ from the basin length using the scraper capacity formulation set forth in Eq. (1). The scraper transport capacity as a function of scraper flight height $\left(h_{\mathrm{sf}}\right)$, speed, and tank length is defined in Table 1 for the operating conditions set forth earlier. The sludge quantity to be removed per foot of tank width will be $0.37 \mathrm{~m}^{3} / \mathrm{m}^{2} \mathrm{~h}$ times the basin length. The full basin length is employed since the inlet turbulence normally prevents sludge deposition in the area of the sludge trough of clarifiers in the countercurrent flow mode, the most common type of rectangular clarifier mechanism design.

The effect of operating the scrapers at higher speeds on the final concentration of the RAS has not been reported in the literature. The higher RSS concentrations achieved by modified units at Phoenix 91st Avenue may be mostly a function of reduced short-

Theoretical Transport Capacity $-\mathrm{m}^{3} / \mathrm{hr} \cdot \mathrm{m}$

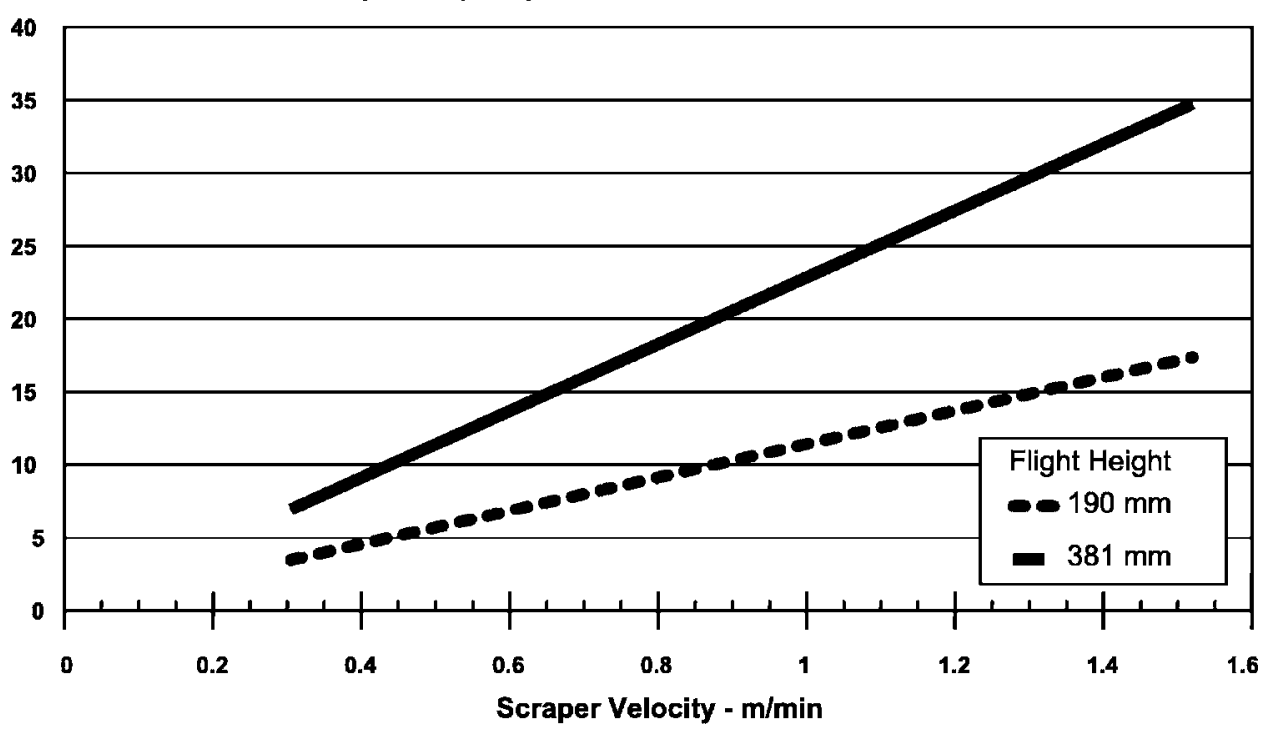

Fig. 3. Theoretical transport capacity of longitudinal scrapers 
circuiting of MLSS to the underflow. Further, the actual transport capacity ratio to the theoretical capacity may range from 0.8 to nearly 1.0, but it is suggested that a 0.8 factor be employed at this time and $V_{\mathrm{SC}}$ applied to the scraper capacities set forth in Fig. 3. That is, the theoretical scraper transport capacity, $V_{\mathrm{SC}}$, should be $\geqslant 1.25$ times the maximum RAS flow. The theoretical capacity of the scrapers as a function of scraper height and speed is shown in Fig. 3.

Thus, for a secondary clarifier with a SLR of $4.07 \mathrm{~kg} / \mathrm{m}^{2}$ day, the RAS rate for a $48.8 \mathrm{~m}$ long clarifier would be $\left(0.37 \mathrm{~m}^{3} / \mathrm{m}^{2} \mathrm{~h}\right)\left(47.8 \mathrm{~m}^{2} / \mathrm{m}\right) / 60 \mathrm{~min} / \mathrm{h}$ or $0.30 \mathrm{~m}^{3} / \mathrm{min} \mathrm{m}$ of trough width. Employing a design/theoretical transport efficiency of 0.8 results in a minimum transport capacity of $(1.25)(0.30)$ or $0.375 \mathrm{~m}^{3} / \mathrm{min} \mathrm{m}$ and $380 \mathrm{~mm}$ deep scrapers operating at $\geqslant 1.0 \mathrm{~m} / \mathrm{min}$ (Table 1) would meet this requirement.

\section{Cross Collectors}

The aforementioned $48.8 \mathrm{~m}$ long clarifier has a $12.2 \mathrm{~m}$ width and an existing transverse trough to collect sludge from the longitudinal collectors at the influent end. The trough is $2.44 \mathrm{~m}$ wide tapering to $1.22 \mathrm{~m}$ at $1.83 \mathrm{~m}$ of depth. The cross-collector has $190 \mathrm{~mm}$ deep flights and operates at $1.22 \mathrm{~m} / \mathrm{min}$, discharging the sludge to a $1.22 \mathrm{~m} \times 1.22 \mathrm{~m}$ hopper located at the clarifier side and connected to the RAS pipe. The limitations of the typical cross-collectors to transport the concentrated sludge to the hopper are revealed in the following calculations using the data from Table 1

RAS flow to hopper $=\left(0.30 \mathrm{~m}^{3} / \mathrm{min} \mathrm{m}\right)(12.2 \mathrm{~m})=3.66 \mathrm{~m}^{3} / \mathrm{min}$

$$
\text { scraper capacity } \begin{aligned}
\left(V_{\mathrm{SC}}\right) & =(1.22 \mathrm{~m})(0.190 \mathrm{~m})(1.22 \mathrm{~m} / \mathrm{min}) \\
& =0.282 \mathrm{~m}^{3} / \mathrm{min}
\end{aligned}
$$

The mechanical transport capacity $\left(V_{\mathrm{SC}}\right)$ of the cross-collectors is $<10 \%$ of the RAS volume delivered to the trough. While there will be a sludge density effect causing flow towards the hopper, it is not sufficient to prevent flow from the much closer influent MLSS overlying the sludge blanket ("rat-holing"). That is, the dilute liquid, about 1.5-2.2 $\mathrm{m}$ above the trough and hopper, will flow easier to the RAS line than the concentrated sludge. The concentrated sludge would then need to flow a distance up to 3-6 $\mathrm{m}$ in the trough at a much higher velocity than the scraper speed and this is not possible. When dilution of the underflow occurs, the RAS must be increased to maintain the MLSS concentration, which, in turn, raises the SLR and worsens the shortcircuiting condition. These calculations provide a good support for the 1968 shortcircuiting observations of FWQA investigators Pfeffer and Myers as well as Günthert's studies.

The use of cross-collectors is an ineffective method of removing collected sludge from the trough. Two different concepts can be considered: (1) a pipe with openings connected to the RAS pipe and that extends the length of the trough; and (2) or a channel in the lower portion of the hopper with a series of openings and the cross-collector passing over the top of the channel to prevent deposition between the openings. The area of openings and size would be based on about $0.91 \mathrm{~m} / \mathrm{s}$ entrance velocity at the maximum RAS flow.

$$
\begin{aligned}
\text { total area }= & \left(3.66 \mathrm{~m}^{3} / \mathrm{min}\right)(1.2 \text { peaking factor }) /(60 \mathrm{~s} / \mathrm{min}) \\
& \times(0.91 \mathrm{~m} / \mathrm{min})=0.813 \mathrm{~m}^{2}\left(81,300 \mathrm{~mm}^{2}\right)
\end{aligned}
$$

size opening $=\left(81,300 \mathrm{~mm}^{2}\right) / 10$ inlets $=8,133 \mathrm{~mm}^{2} /$ inlet

The openings can be circular, square, or rectangular, whichever would be the simplest to install. If circular holes were employed, then ten openings averaging about $102 \mathrm{~mm}$ diameter would be provided at $1.22 \mathrm{~m}$ center to center. Due to momentum and velocity effects, the size of openings are variable with the largest opening at the furthest point. The area of the collection device would be tapered to maintain a velocity of $>0.6 \mathrm{~m} / \mathrm{s}$ and the RAS pipe would be 300 or $350 \mathrm{~mm}$ diameter. Thus, it may be easiest to construct a rectangular cross section to be placed in the bottom of the existing trough as shown in Fig. 4. The area around the trough can be filled in with concrete to the top of the header. The cross-collector can then be reset to keep the top of the header clear of sludge deposits, which could gasify and then float.

It is not known whether it will be necessary to retain the crosscollector with the header. Full-scale tests will be conducted at the Blue Plains WWTP, Washington, D.C. The 24 secondary clarifiers are 76.2 and $279.2 \mathrm{~m}$ long and have the collection trough in the middle of the $24.2 \mathrm{~m}$ wide tank. The cross-collector had only a small fraction of the capacity necessary to transport the concentrated sludge to the RAS pipe located at one side of the basin. The collection alternatives are a tapered trough (Fig. 4) and a dual suction pipe. The cross-collectors can be turned off to determine whether they are needed. These tests should define whether retaining the cross-collectors with the new header arrangements are necessary. The tests will be initiated in the spring of 2007 .

Construction of a new clarifier would permit design of the trough section to be much smaller since the trough sludge residence time is not significant. For the $12.2 \mathrm{~m}$ wide $\times 48.8 \mathrm{~m}$ long clarifier, a trough $1.5 \mathrm{~m}$ wide, $3.7 \mathrm{~m}$ long, and $1.5 \mathrm{~m}$ deep tapering to the diameter of the RAS pipe at the bottom of the hopper would be adequate. In this case, a $0.3 \mathrm{~m}$ diameter RAS pipe will provide a volume of $1.3 \mathrm{~m}^{2} / \mathrm{m}$ of hopper length. This results in a residence time equal to $1.35 \mathrm{~m}^{3} / 0.30 \mathrm{~m}^{3} / \mathrm{min} \mathrm{m}$ or $4.6 \mathrm{~min}$ of residence time. Since the scrapers are operating at about $1 \mathrm{~m} / \mathrm{min}$ and the scraper spacing is $3.05 \mathrm{~m}$ center to center, there would be a longitudinal scraper approaching the hopper every $3.0 \mathrm{~min}$. The trough should have adequate volume to prevent emptying the hopper between arrival of a flight. The scrapers can be operated at higher speed producing a proportionally higher transport rate or install the scrapers closer together if residence time in the trough is too low and shortcircuiting of the MLSS to the underflow occurs.

\section{Other Design Considerations}

\section{Floor Slope}

It is not unusual for rectangular clarifiers to have a shallow floor slope, which can result in less than a $300 \mathrm{~mm}$ difference in water depth at the sludge hopper. In the foregoing example, the partially concentrated sludge during the maximum month had an average depth of $0.384 \mathrm{~m}$ or equal to the height of the scraper. During peak flow periods, there can be a large inventory shift from the aeration basins to the clarifiers. It is neither feasible nor the correct operating practice to increase RAS flow above a specific point, generally $\leqslant 0.7$ of the maximum month influent flow, since this can increase the SLR above the design loading.

The normal effect is a short-term increase in the clarifier solids inventory which is reflected in a deeper blanket. This peak flow increase in the sludge blanket depth should not exceed $0.75 \mathrm{~m}$ 

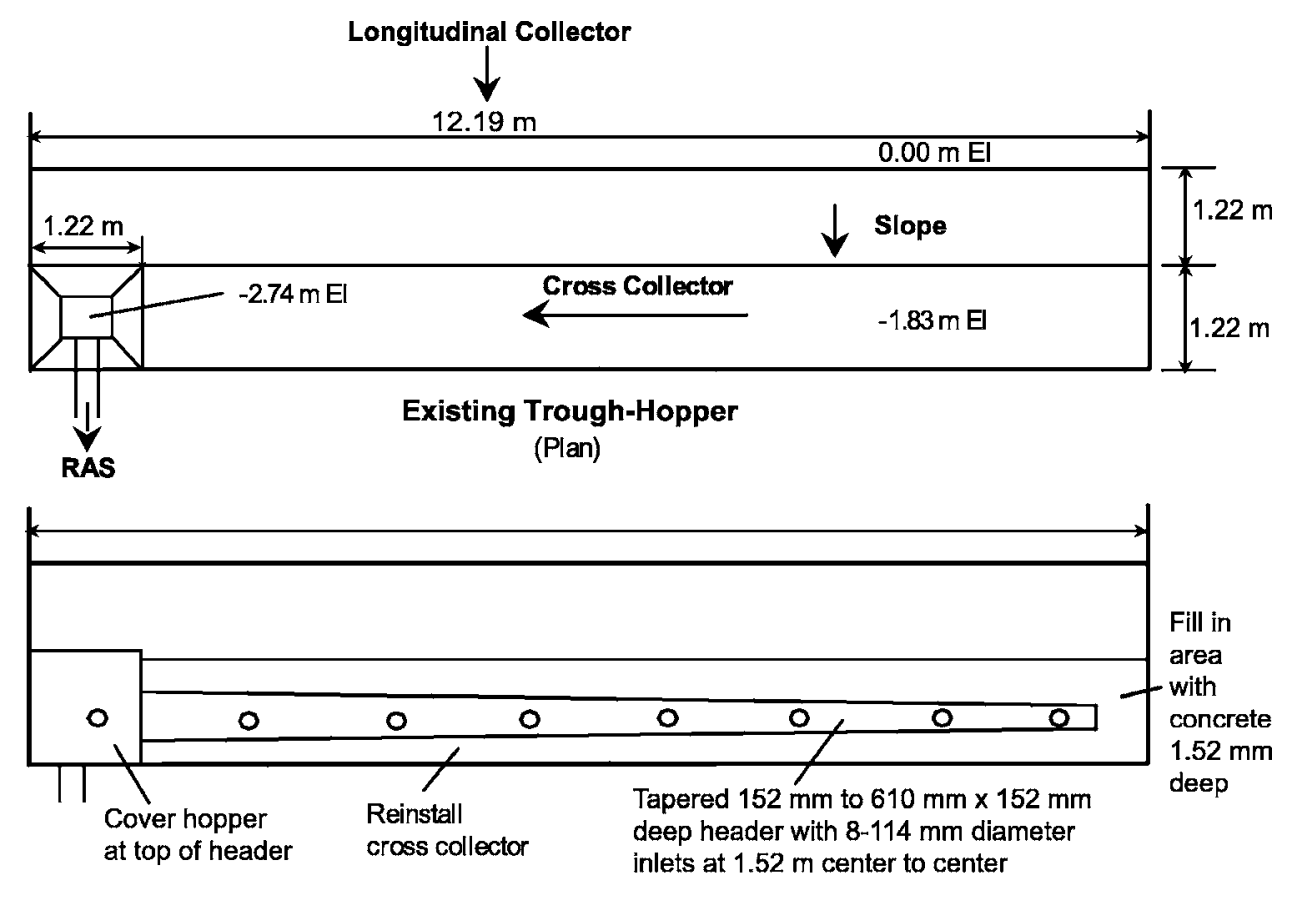

Modified Trough-Hopper

(Plan)

Fig. 4. Rectangular clarifier sludge collection header

and should be less in basins shallower than $3.66 \mathrm{~m}$. More than $0.9 \mathrm{~m}$ increase in sludge depth is excessive and can cause performance problems. The effect of the floor slope on the sludge blanket depth in the $48.8 \mathrm{~m}$ long secondary clarifier during a peak flow aeration solids inventory shift is shown in Table 2 . The normal settled sludge inventory would be $(0.384 \mathrm{~m})\left(48.8 \mathrm{~m}^{2} / \mathrm{m}\right)$ or $18.74 \mathrm{~m}^{3} / \mathrm{m}$ of basin width. The range in depth of the sludge blanket in the clarifier would be a function of the floor slope.

Typically, the diurnal flow will result in inventory shifts equal to a $0.305 \mathrm{~m}$ or less increase in the sludge blanket depth. During wet weather flows the increase should be limited to $0.61-0.76 \mathrm{~m}$. Excessive SBRT, especially in BNR systems, can cause denitrification and loss of solids to the overflow. However, the slope of the floor can play an important role in minimizing the presence of sludge in the area of the weirs and launder. As shown in Table 2 employing earlier calculations, a $381 \mathrm{~mm}$ deep scraper at $1.0 \mathrm{~m} / \mathrm{min}$ would remove settled sludge from the effluent end until the inventory shift was equivalent to $>0.6 \mathrm{~m}$ of sludge over the total area with a $0.61 / 48.8 \mathrm{~m} / \mathrm{m}$ slope. A $1.22 \mathrm{~m}$ slope would further limit denitrification in the area of the effluent launders with $0.305 \mathrm{~m}$ of inventory shift, and the deep flights would continuously move $0.38 \mathrm{~m}$ of the "oldest" sludge toward the collection trough.

In the countercurrent flow mode, the steeper floor slope is also a positive factor in reducing scour of the sludge blanket and reducing influent energy. It plays a similar role comparable to the deepened center area of circular clarifiers to reduce scour effects. If scour occurs, solids are displaced toward the effluent end and then there is an increase in the SLR on the collectors. When collector capacity is exceeded, sludge accumulates at the effluent end under the weirs.

\section{Countercurrent or Cocurrent Mode}

The Envirex (1953) studies showed that cocurrent flow and sludge collection were more efficient than countercurrent mode, the most common arrangement. While the scrapers in the study of the cocurrent flow did not move more of the consolidated sludge than the scrapers in the countercurrent flow, the more dilute

Table 2. Effect of Aeration Inventory Shift on Sludge Blanket Depths

\begin{tabular}{|c|c|c|c|c|}
\hline \multirow{2}{*}{$\begin{array}{l}\text { Parameter } \\
\text { floor slope }\end{array}$} & \multirow{2}{*}{$\begin{array}{l}\text { Units } \\
\mathrm{m} / 48.8 \mathrm{~m}\end{array}$} & \multicolumn{3}{|c|}{ Sludge depth at effluent/hopper end } \\
\hline & & 0.61 & 0.91 & 1.22 \\
\hline \multicolumn{5}{|l|}{ Operating condition } \\
\hline Volume at $0.61 \mathrm{~m}^{3} / \mathrm{m}$ & $\mathrm{m} / \mathrm{m}$ & $0.08 / 0.69$ & $0.00 / 0.84$ & $0.00 / 0.97$ \\
\hline Inv shift of $0.305 \mathrm{~m}$ & $\mathrm{~m} / \mathrm{m}$ & $0.38 / 0.99$ & $0.23 / 1.15$ & $0.08 / 1.30$ \\
\hline Inv shift of $0.61 \mathrm{~m}$ & $\mathrm{~m} / \mathrm{m}$ & $0.69 / 1.30$ & $0.54 / 1.45$ & $0.38 / 1.60$ \\
\hline Inv shift of $0.91 \mathrm{~m}$ & $\mathrm{~m} / \mathrm{m}$ & $0.99 / 1.60$ & $0.84 / 1.76$ & $0.69 / 1.91$ \\
\hline
\end{tabular}


91st Ave WWTP - Phoenix, AZ

Existing Clarifier

Feb $13,1993-4$ to $5 \mathrm{pm}$
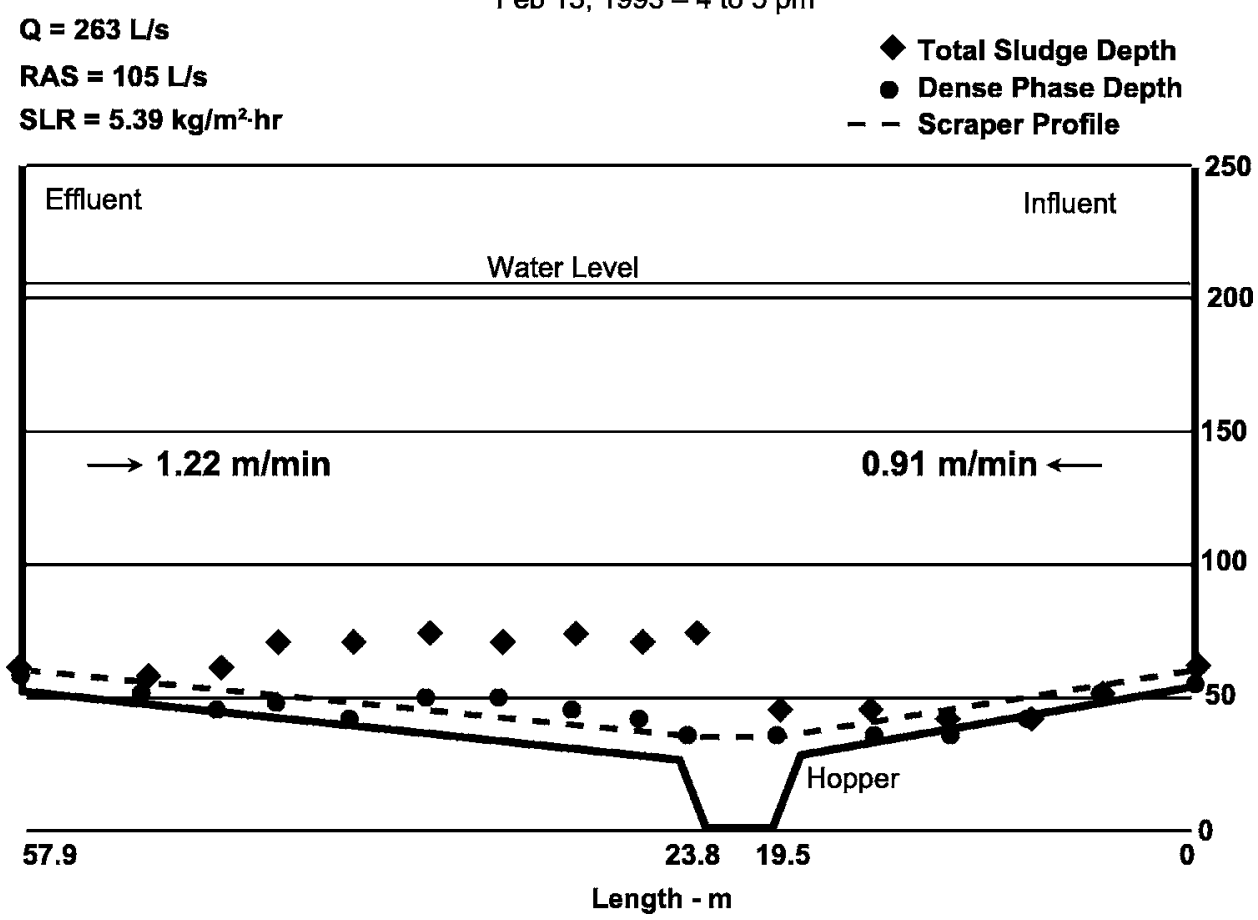

Fig. 5. Phoenix 91st Ave. Plant 3A-typical sludge blanket location in existing clarifier

sludge blanket was flowing with the mechanism. In the cocurrent mode at the influent end, there was scouring of settled sludge from between the flights - a condition observed in studies prior to modifications to the secondary clarifiers at Phoenix 91st Avenue, Ariz. WWTP.

Wahlberg et al. (1994) reported studies on the secondary clarifiers at the San Jose Creek WWTP in Whittier, Calif. The performance of these $45.7 \mathrm{~m}$ long $\times 6.1 \mathrm{~m}$ wide units with the sludge collection trough at the effluent end (Gould tank Type I) was exceptional up to an overflow rate (OFR) of $3 \mathrm{~m} / \mathrm{h}$ and SLR of $4.88 \mathrm{~kg} / \mathrm{m}^{2} \mathrm{~h}$. These units had an average depth of $3.05 \mathrm{~m}$ and a floor slope of $0.46 \mathrm{~m} / 45.7 \mathrm{~m}$. The data did not reveal any significant correlation between the OFR and effluent TSS over the typical flow range of the clarifier operation.

The San Jose Creek wastewater treatment plant operates the aeration basin in a reaeration-step feed mode in the four-pass basins. The system is in a non-nitrifying mode of secondary treatment. The operating MLSS is $1,000-1,200 \mathrm{mg} / \mathrm{L}$ at $50 \%$ $\mathrm{RAS} / Q$, thus the RSS is $3,000-3,600 \mathrm{mg} / \mathrm{L}$, a very low concentration.

The question of whether the cocurrent mode is applicable to nitrifying systems has not been evaluated. There would be concern of having thickened sludge with 45-60 min of SBRT present under the area of launders and weirs. Typically, in warmer weather, 8,000-12,000 $\mathrm{mg} / \mathrm{L}$ TSS in the sludge blanket would result in complete denitrification and possibly a major loss of TSS over the weirs located near the sludge hopper.

\section{Phoenix 91st Avenue WWTP Improvement Programs}

In the early 1990s, pilot studies were authorized by the joint owners of 91st Avenue WWTP in Tolleson, Ariz. The purpose of the studies was to optimize the capacity of the $6.75 \mathrm{~m}^{3} / \mathrm{s}$ wastewater treatment plant in a conversion from secondary treatment to BNR with a total nitrogen limitation of $10 \mathrm{mg} / \mathrm{L}$. The pilot studies were full scale at $1.32 \mathrm{~m}^{3} / \mathrm{s}$ and conducted in Plant $3 \mathrm{~A}$ of the facilities. The results of the study, conducted over a 2-year period, were previously reported (Stensel et al. 1993; Albertson and Coughenour 1995). These studies were successful and resulted in the full conversion of the $6.75 \mathrm{~m}^{3} / \mathrm{s}$ facility to BNR by the late 1990s without loss of the rated capacity of aeration basins and the rectangular clarifiers in Plants $2 \mathrm{~B}$ and $3 \mathrm{~A}$. Older rectangular basins in Plants $1 \mathrm{~A}, 1 \mathrm{~B}$, and $2 \mathrm{~A}$ were replaced by large circular clarifiers.

It was recognized prior to the study that the rectangular secondary clarifiers would have limited the plant capacity in Plants 2B $\left(1.58 \mathrm{~m}^{3} \mathrm{~s}\right)$ and $3 \mathrm{~A}\left(1.32 \mathrm{~m}^{3} \mathrm{~s}\right)$ when the MLSS was increased from $600-800$ to $3,500 \mathrm{mg} / \mathrm{L}$. Severe sludge bulking conditions at low MLSS concentrations resulted in sludge blanket accumulations in the effluent end of the basin at SLRs of less than $1.22 \mathrm{~kg} / \mathrm{m}^{2}$ day. The renovation would result in maximum month SLRs up to $5.1-6.1 \mathrm{~kg} / \mathrm{m}^{2}$ day at $3,500 \mathrm{mg} / \mathrm{L}$ MLSS when bioselectors were employed to control bulking and to increase the biological treatment capacity.

There were $8-57.9 \mathrm{~m}$ long $\times 12.2 \mathrm{~m}$ wide $\times 4.11-3.81 \mathrm{~m}$ SWD secondary clarifiers in Plant $3 \mathrm{~A}$. The sludge trough was centered at $21.6 \mathrm{~m}$ and was $4.27 \mathrm{~m}$ wide tapering to $3.66 \mathrm{~m}$ at $1.52 \mathrm{~m}$ deep. The sludge blanket profiles prior to modifications are shown in Fig. 5. The longitudinal collectors were cocurrent at the influent end and countercurrent to flow at the effluent end. The two cross-collectors move sludge to the trough center for withdrawal. The influent structure consisted of 40-152 mm $\varnothing$ openings in the upper $75 \%$ of wall height.

Overhead viewing of the secondary clarifiers from a $30.5 \mathrm{~m}$ high crane bucket revealed turbulence in the initial $30 \%$ of the 


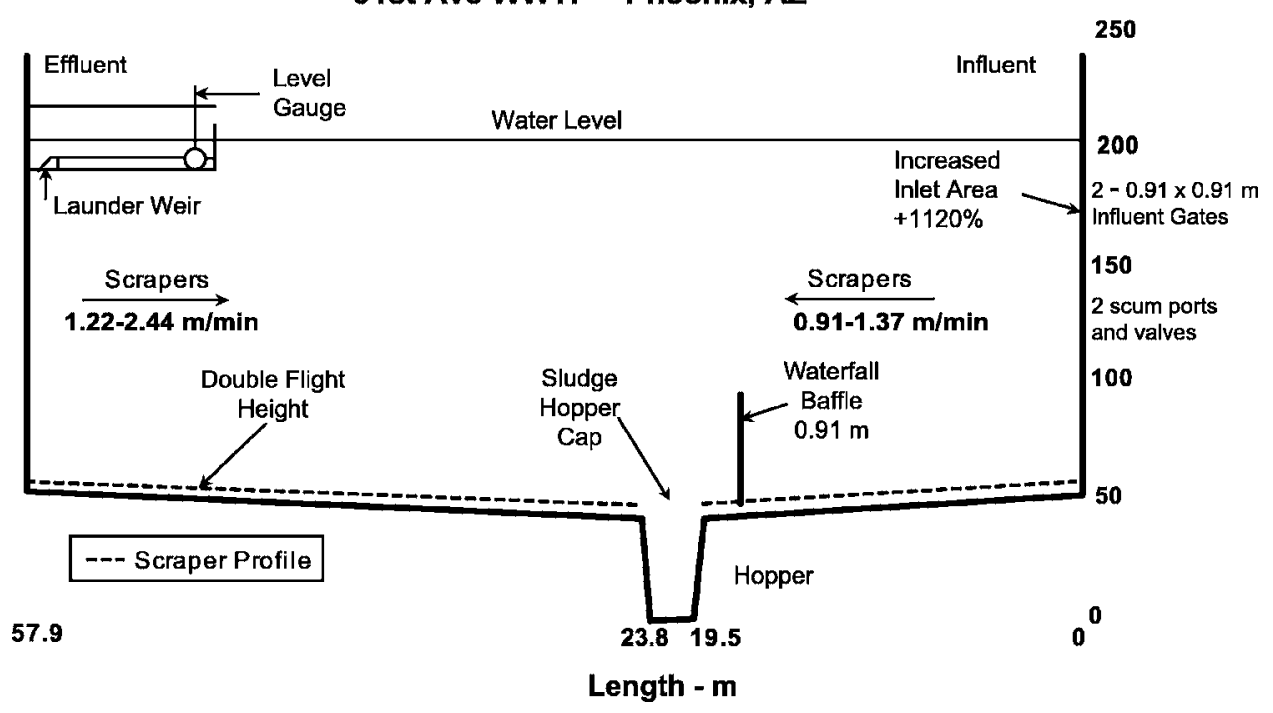

Fig. 6. Phoenix 91st Ave. Plant 3A-modification to rectangular clarifiers

basin. The velocity of the MLSS through the openings at average flow was $0.27 \mathrm{~m} / \mathrm{s}$ and about $0.38 \mathrm{~m} / \mathrm{s}$ at the average diurnal peak flow. A significant waterfall effect was still present and sludge judge samples revealed that the influent flow scoured all sludge from the cocurrent flights in the first $19.5 \mathrm{~m}$ of the clarifier. The result was that the $34.1 \mathrm{~m}$ in the rear of the basin was overloaded by the sludge scoured from the initial $19.5 \mathrm{~m}$ of the basin, increasing the SLR about $60 \%$ in the countercurrent sludge collection zone. This triggered sludge buildup in the effluent zone during the peak diurnal flow each day and increased solids loss. Sampling of the sludge blanket and the RAS revealed that MLSS was short circuiting and diluting the underflow. Launder water depths indicated $\pm 10 \%$ difference in the overflow rates from the average rate of eight settling basins, resulting in variable performances during peak flow conditions.

With the conversion of the aeration basins to BNR and the provision of bioselection for bulking control, a prototype of the secondary clarifier was also completed. The clarifier modifications, depicted in Fig. 6, included: (1) increasing the inlet area $1,100 \%$ and reducing the velocity to $0.024-0.034 \mathrm{~m} / \mathrm{s}$; (2) construction of a $0.91 \mathrm{~m}$ high waterfall wall at about $16.7 \mathrm{~m}$ from the inlet to prevent scour in the influent end and hopper area and to encourage sludge settlement in the influent end; (3) double height scrapers $(381 \mathrm{~mm})$ to increase transport capacity, up to $1.83 \mathrm{~m} / \mathrm{min}$ scraper speed; (4) a cover over the area of the sludge withdrawal pipe to reduce rat-holing effects; and (5) launder dams with a measurement for balancing the influent flows to each basin.

Transport characteristics were defined by the level of the sludge blanket, both dense and diffuse, as well as the solids concentration of the dense phase of the blanket.

Duplicate samples were taken with a sludge judge at 3.0-3.7 $\mathrm{m}$ intervals along the basin length. Initial testing had determined that the flights moved only the volume of sludge about equal to their height. That is, if there was $250 \mathrm{~mm}$ of dense sludge in front of a $191 \mathrm{~mm}$ flight, there would be $50-75 \mathrm{~mm}$ of sludge immediately after the flight passed. These results were similar to the transport characteristics in the movie filmed by Envirex (1953) when influent flow and sludge flow are countercurrent.

The sludge blanket characteristics of the secondary clarifiers with and without modifications were evaluated once the aeration basins were converted to the nitrification-denitrification (NdeN) mode with bioselection to reduce the SVI to less than $100 \mathrm{~mL} / \mathrm{g}$. The before and after plots of the dense and diffuse phase sludge blankets are shown in Figs. 5 and 7 when SVI was $<100 \mathrm{~mL} / \mathrm{g}$. Once the SVI was reduced, both modified and unmodified clarifier plots had a significantly higher capacity. However, at the MLSS levels of 3,200-3,500 mg/L, effluent TSS were higher in the unmodified units, especially during the peak diurnal flows. The sludge blankets in those units extended to the back wall as shown in Fig. 5. The influent flow through the perforated wall and subsequent added waterfall effect scoured the settled sludge from the first $19.5 \mathrm{~m}$ of the basin.

After modifications the waterfall baffle caused sludge to settle in the initial section of the clarifier (Fig. 7) and the $381 \mathrm{~mm}$ deep scrapers at $1.83 \mathrm{~m} / \mathrm{min}$ produced a dense sludge blanket in the first $16.7 \mathrm{~m}$ of the $57.9 \mathrm{~m}$ long basin at an $11 \%$ higher SLR. The presence of this blanket dampened the waterfall effect at the inlet. The average MLSS was $3,350 \mathrm{mg} / \mathrm{L}$ and the RSS averaged $11,200 \mathrm{mg} / \mathrm{L}$ or significantly higher than the $8,500 \mathrm{mg} / \mathrm{L}$ in the unmodified clarifiers.

The two aeration basins and the $8-70.1 \mathrm{~m}$ long $\times 12.2 \mathrm{~m}$ wide $\times 3.73 \mathrm{~m}$ water depth $(\mathrm{WD})$ secondary clarifiers at Plant $3 \mathrm{~A}$ were modified after the successful 18-month demonstration tests. Typical effluent TSS was 4-8 mg/L during the 18-month Plant 3A study in 1993-1995. Later, Plant 2B aeration basins and secondary clarifiers were modified using the same approach.

\section{Summary and Conclusions}

The problem of shortcircuiting of MLSS to the underflow of rectangular basins was likely known prior to the FWQA studies in the 1960 s. The FWQA studies revealed that up to $50 \%$ of the underflow was mixed liquor, which diluted the return sludge and increased the return rate. This effect, in turn, increased the SLR. It would be reasonable to expect that increasing the RAS/ $Q$ rate would only exacerbate the situation as shortcircuiting would also increase. This effect was also shown by Günthert in his study of sludge transport in circular secondary clarifiers. This problem is more prevalent in the longer, wider rectangular basins that have 


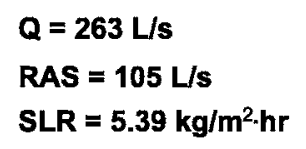

$Q=263 \mathrm{~L} / \mathrm{s}$

$S L R=5.39 \mathrm{~kg} / \mathrm{m}^{2} \times \mathrm{hr}$

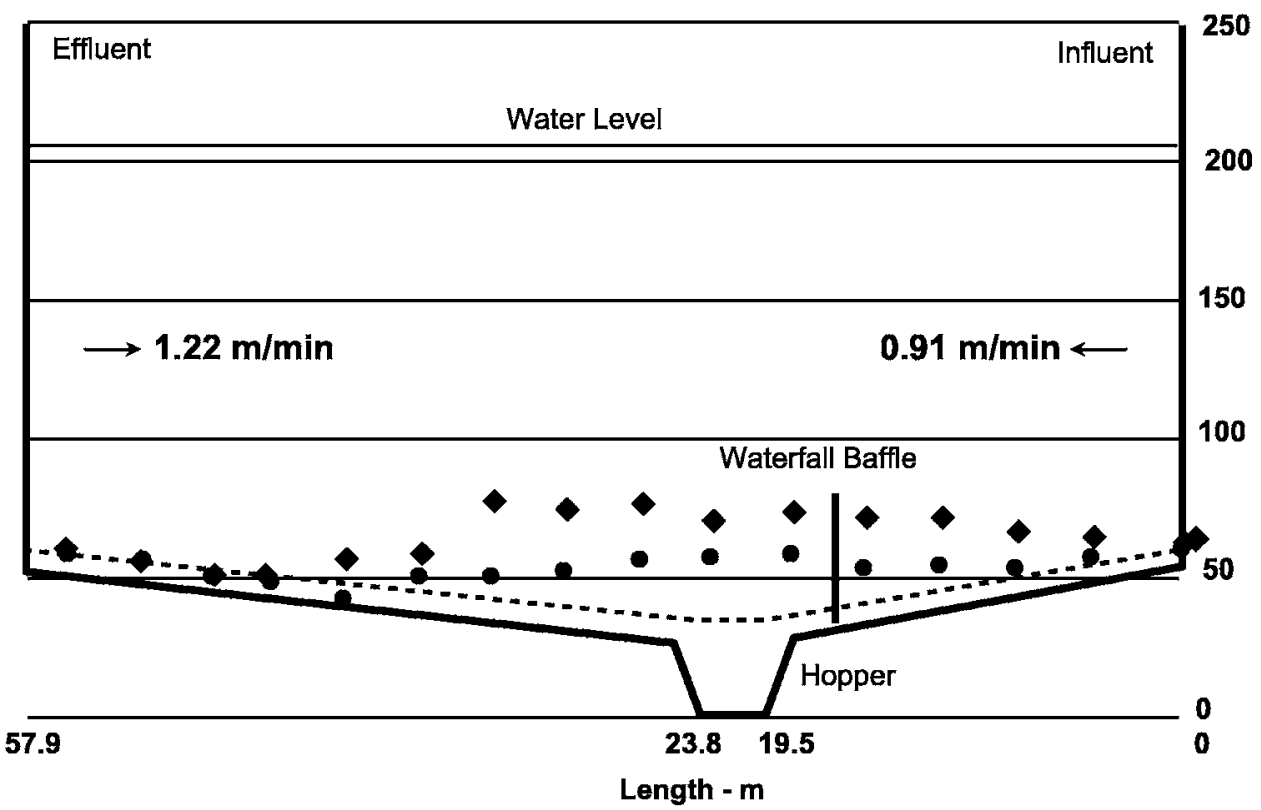

Total Sludge Depth

- Dense Phase Depth

- - Scraper Profile

Fig. 7. Phoenix 91st Ave. Plant 3A—sludge blanket location after improvements to clarifier

higher transport requirements and is also a product of increasing the SLR $250-500 \%$ in the BNR mode of operation at MLSS of 3,000-4,000 mg/L. However, the Phoenix 91st Avenue fullscale studies of modified rectangular clarifiers demonstrated that these shortcomings could be eliminated.

Specific recommendations for the design of the longitudinal and cross-collectors are as follows:

1. Define the maximum transport requirements (RAS flow) based on the SLR and the return sludge concentration. The lower return concentration consistent to the highest weekly SVI should be employed;

2. Establish the longitudinal scraper height and speed based on a theoretical transport capacity equal to $125 \%$ of the maximum RAS flow;

3. Provide variable frequency drives for the longitudinal collectors such that the speed employed can be consistent with the return rate needed as a function of the SVI and the SLR. The speed range should be at least $0.61-2.44 \mathrm{~m} / \mathrm{min}$;

4. Replace cross-collector concepts with sludge collection headers in both existing and new rectangular clarifiers. In existing basins with large troughs the cross-collector may be reinstalled above the collector to prevent depositiongasification;

5. Provide about $0.9 \mathrm{~m}$ additional depth (or $2.5 \%$ of basin length) at the inlet end in new basins to minimize peak flow sludge accumulation at the effluent end as well as to reduce scour of settled sludge and eliminate shortcircuiting;

6. Waterfall walls have proven effective in breaking up the plunging, scouring MLSS influent, and increasing settlement in the initial portion of the clarifier. Install box structures over the inlets to slow the flow and redirect it to $90^{\circ}$ to the basin length, which also provides effective flocculation;

7. The cocurrent mode of flow and mechanism has shown benefits in a non-nitrifying mode at MLSS $<2,000 \mathrm{mg} / \mathrm{L}$. However, there is concern for BNR systems at MLSS $>3,000 \mathrm{mg} / \mathrm{L}$ that denitrification and the resulting rising TSS will impair effluent quality if the hopper is located under the weir and launders; and

8. The maximum length of the longitudinal collector may be in the range of $45.7-48.8 \mathrm{~m}$ with peak SLRs of about $5.1 \mathrm{~kg} / \mathrm{m}^{2}$ day. Longer basins will need two collection troughs (single mechanism) or a trough near the tank center (dual mechanism.)

\section{Postscript}

The improved rectangular clarifiers at Phoenix 91st Avenue WWTP have continued to provide excellent service in the last 10 years. A comparison of Plants $2 \mathrm{~B}$ and $3 \mathrm{~A}$ performances with the other plants that are equipped with circular clarifiers in the 91st Avenue complex is provided in Table 3. The bioselectors in the ten-stage (except 2A) aeration basins have produced average DSVIs $<90 \mathrm{~mL} / \mathrm{g}$, averaging $82 \mathrm{~mL} / \mathrm{g}$ for the six independent plants. No differences in the return sludge or secondary effluent (SE) quality were found. However, the circular clarifier operates at a higher OFR and Plant 2A has a different aeration configuration, which is less efficient and thus operates at a much lower OFR. 
Table 3. Summary of 2004 Phoenix 91st Avenue Average Annual Results

\begin{tabular}{|c|c|c|c|c|c|c|c|}
\hline \multirow[b]{2}{*}{$\begin{array}{l}\text { Parameter } \\
\text { clarifier type }\end{array}$} & \multirow[b]{2}{*}{ Units } & \multicolumn{6}{|c|}{ Plant number } \\
\hline & & $\begin{array}{c}1 \mathrm{~A} \\
\text { Circ. }\end{array}$ & $\begin{array}{c}\text { 1B } \\
\text { Circ. }\end{array}$ & $\begin{array}{c}2 \mathrm{~A} \\
\text { Circ. }\end{array}$ & $\begin{array}{l}2 \mathrm{~B}^{\mathrm{a}} \\
\text { Rect. }\end{array}$ & $\begin{array}{l}3 \mathrm{~A}^{\mathrm{a}} \\
\text { Rect. }\end{array}$ & $\begin{array}{c}\text { 3B } \\
\text { Circ. }\end{array}$ \\
\hline AB flow & mg day & 27.45 & 27.47 & 9.62 & 24.41 & 24.62 & 25.18 \\
\hline RAS flow & mg day & 14.16 & 14.21 & 5.28 & 12.13 & 12.30 & 11.55 \\
\hline AB SRT & days & 7.71 & 7.36 & 7.15 & 6.19 & 8.28 & 7.77 \\
\hline AB MLSS & $\mathrm{mg} / \mathrm{L}$ & 3,187 & 3,148 & 2,884 & 3,122 & 3,158 & 3,168 \\
\hline AB RSS & $\mathrm{mg} / \mathrm{L}$ & 10,344 & 10,321 & 10,501 & 10,942 & 10,529 & 10,661 \\
\hline AB DSVI & $\mathrm{mL} / \mathrm{g}$ & 77 & 79 & 88 & 83 & 78 & 87 \\
\hline SC OFR & $\mathrm{m} \mathrm{h}$ & 0.92 & 0.92 & 0.36 & 0.56 & 0.69 & 0.84 \\
\hline SC SLR & $\mathrm{kg} / \mathrm{m} \mathrm{h}$ & 4.92 & 4.92 & 2.09 & 3.07 & 3.65 & 4.13 \\
\hline SE COD ${ }^{b}$ & $\mathrm{mg} / \mathrm{L}$ & 31 & 30 & 26 & 29 & 31 & 25 \\
\hline SE TSS & $\mathrm{mg} / \mathrm{L}$ & 9 & 8 & 5 & 10 & 8 & 5 \\
\hline $\mathrm{SE} \mathrm{NH}_{4}-\mathrm{N}^{\mathrm{c}}$ & $\mathrm{mg} / \mathrm{L}$ & 2.4 & 2.1 & 2.8 & 1.9 & 1.8 & 1.6 \\
\hline SE TN & $\mathrm{mg} / \mathrm{L}$ & 5.9 & 6.0 & 7.7 & 8.6 & 6.5 & 6.0 \\
\hline
\end{tabular}

${ }^{\mathrm{a}}$ Improved rectangular basins in 1995 .

${ }^{\mathrm{b}}$ Total effluent $\mathrm{cBOD}_{5}=<2-3 \mathrm{mg} / \mathrm{L}$.

${ }^{\mathrm{c}}$ Target $\mathrm{NH}_{4}-\mathrm{N}=2.0 \mathrm{mg} / \mathrm{L}$.

\section{References}

Albertson, O. E. (1992). "Control of bulking and foaming organisms." Design and retrofit of wastewater treatment plants for biological nutrient removal, Chap. 8, C. Randall et al., eds., International Association of Water Quality (IAWQ), Technomic Publishing Company Inc., Lancaster, Pa.

Albertson, O. E. (2005). "Activated sludge bioselector processes." Rep. Prepared for the Water Environment Research Foundation, Alexandria, Va.

Albertson, O. E., and Coughenour, J. (1995). "Aerated anoxic oxidationdenitrification process." J. Environ. Eng., 121(10), 720-726.

Albertson, O. E., and Okey, R. W. (1992). "Evaluating scraper designs." Water Envir. Tech., 4(1), 52-58.

ASCE. (1998). Design of municipal wastewater treatment plants, manual and report on engineering practice, No. 76, American Society of Civil Engineers and Water Environment Federation, MOP No. 8, Alexandria, Va.

Daigger, G. T. (1995). "Development of refined clarifier operating diagrams using an updated settling characteristics database." Water Environ. Res., 67(1), 95-100.

Daigger, G. T., and R. E. Roper (1985). "The relationship between SVI and activated sludge settling characteristics." J. Water Pollut. Control Fed., 57, 859.

Envirex. (1953). A movie tape of model studies of activated sludge transport in co-current and counter-current modes of operation, Milwaukee, Wis.
Günthert, F. W. (1984). "Thickening zone and sludge removal in circular final settling tanks." Water Sci. Technol., 16, 303.

International Association of Waste Quality (IAWQ). (1997). "Secondary settling tanks-Theory, modeling, design and operation." Scientific and Technical Rep. No. 6, G. A. Ekama et al., eds, IAWQ, London.

Kalbskopf, K. H. (1970). "European practices in sedimentation." Water quality improvement by physical and chemical processes, E. F Gloyna and W. W. Eckenfelder, Jr., eds., University of Texas Press, Austin, Tex., 92-103.

Kalbskopf, K. H. (1972). "Discussion of the design parameter for secondary sedimentation tanks." Water Res., 6, 429-431.

Myers, L. H., et al. (1968). "Phosphate removal by activated sludge, amenability studies at Indianapolis, Indiana." National Technical Information Serivce (NTIS) No. PB-226-381, Robert S. Kerr Environmental Research Center, Ada, Okla.

Pfeffer, F. M., et al. (1968). "Phosphate removal by activated sludge, amenability studies at Pontiac, Michigan." NTIS NO. PB-226-379, Robert S. Kerr Environmental Research Center, Ada, Okla.

Stensel, H. D., Albertson, O. E., and Hendricks, P. (1993). "Evaluation of anoxic-aerobic treatment of the Phoenix 91st Avenue WWTP." Liquid Process Symp. Proc., of the Water Environment Federation Conf., WEF, Alexandria, Va.

Wahlberg, E. J., et al. (1994). "Evaluating activated sludge clarifier performance using the CRTC protocol: Four case studies." Proc., 67th Annual WEF Conf., WEF, Alexandria, Va., 1-12. 